\title{
Impact of Executive Compensation Incentives on Corporate Tax Avoidance
}

\author{
Yishu Wang ${ }^{1,2}$, Jia Yao ${ }^{1}$ \\ ${ }^{1}$ Business School of Changzhou University, Changzhou, China \\ ${ }^{2}$ Business School of Changshu Institute of Technology, Changshu, China \\ Email: 22403281588@qq.com
}

How to cite this paper: Wang, Y. S., \& Yao, J. (2021). Impact of Executive Compensation Incentives on Corporate Tax Avoidance. Modern Economy, 12, 1817-1834. https://doi.org/10.4236/me.2021.1212094

Received: November 5, 2021

Accepted: December 17, 2021

Published: December 20, 2021

Copyright (c) 2021 by author(s) and Scientific Research Publishing Inc. This work is licensed under the Creative Commons Attribution International License (CC BY 4.0).

http://creativecommons.org/licenses/by/4.0/

\section{(c) (i) Open Access}

\begin{abstract}
The separation of enterprise ownership and control has led to conflicts of interest between its owners and actual managers. Incentives for executives have become an important means to reduce the contradiction between the two. Based on the principal-agent theory and rent-seeking theory, this article selects all listed companies in China from 2013 to 2018 as research samples and divides them into state-owned holding companies and non-state-owned holding companies, exploring the effect of executive compensation incentives on corporate tax avoidance behaviors under the nature of different property rights. The results of the study show that for non-state-owned holding enterprises, executives' monetary remuneration, equity incentives and corporate tax avoidance have a significant positive correlation; for state-owned holding enterprises, there is no significant relationship between executives' monetary remuneration and corporate tax avoidance, and equity incentive is significantly negatively correlated with corporate tax avoidance.
\end{abstract}

\section{Keywords}

Executive Incentives, Corporate Tax Avoidance, Property Nature

\section{Introduction}

For many years, it has been a common method for enterprises to solve governance problems through salary incentives, but it has often caused heated discussions. Because executives and shareholders are in different positions, they have very different expectations for the company. Through different forms of salary incentives, professional managers and shareholders have similar expectations of the enterprise, and then more effectively govern the company. However, when the executives are under different incentives of salary contract, the concealment 
of tax avoidance can cover up their own self-interest behavior, which will lead to two-sidedness of corporate tax avoidance behavior, that is, corporate tax avoidance behavior is promoted or suppressed (Wang, 2018).

Most European and American countries are non-state-owned holding companies. Unlike them, based on China's different institutional environment, state-owned holding companies have an important position in China. Different ownership structures can affect the judgment and decision-making of enterprises. State-owned holding enterprises are controlled by the government, which not only aims at making profits but also reflects the increase of state-owned assets and public welfare, so as to achieve the goal of national economic regulation and regulate the development of the national economy in all aspects. The non-state holding enterprises are private enterprises or private enterprises, whose main goal is to make profits and win wealth for the main shareholders. Therefore, in enterprises with different property rights, the tax avoidance behaviors caused by the incentives of executives cannot be compared. In this paper, the internal microenvironment of enterprises is linked with the government's macro policies, aiming to explore how corporate tax avoidance behavior will change under different forms of compensation incentives of enterprises with different property rights.

At present, numerous researches on the degree of corporate tax avoidance mainly focus on the correlation between the external environment of enterprises and the degree of corporate tax avoidance, such as the relationship between tax regulation and the degree of corporate tax avoidance ( $\mathrm{Wu}, 2018)$, tax avoidance and anti-tax avoidance measures (Chen \& Jiang, 2021). However, starting from the internal financial data of enterprise management, there is relatively little literature on the relationship between executive compensation incentive and tax avoidance degree. However, in contemporary Enterprises in China, the characteristics of the separation of the two rights have gradually matured, and it is more necessary to carry out relevant research based on the principal-agent theory. In this context, the research on the degree of corporate executives' equity incentive and tax avoidance is vacant to a certain extent, which should be grasped.

Based on the above discussion, this article studies the impact of executive compensation incentives on the degree of corporate tax avoidance is of great significance. For companies, first of all, the research results of this article provide business owners with an action guide to improve the incentive system and the company's internal governance regulations. Second, business owners can better grasp the tax avoidance consequences of executive equity incentives to determine whether they can meet the company's profit goals. For the government, this article also has certain reference significance for tax authorities. First of all, to understand the true intentions of the company and go deep into the internal environment of the company, pay attention to the degree of equity incentives for the company's management, and link this factor to the degree of tax avoidance of the company, which will help strengthen the macro grasp of the national tax policy. Secondly, it can effectively alleviate the loss of national taxation and fur- 
ther promote more efficient resource allocation.

In addition, in the existing literature on executive incentives and corporate tax avoidance, this article has a certain degree of innovation. 1) This article divides executive compensation into monetary compensation and equity compensation to explore the impact of different types of compensation on the behavior of executives, which in turn leads to changes in the degree of corporate tax avoidance. 2) Considering China's institutional environment, Chinese enterprises are divided according to the nature of property rights, and the impact of executive compensation incentive on corporate tax avoidance in enterprises with different property rights is discussed.

However, this paper has some limitations. Different industries may have different choices for tax planning. In addition, it is also worth considering whether senior executives have political background. These two factors will also change the impact of executive compensation incentive on corporate tax avoidance. These are areas worth further consideration in the future.

The article is organized as follows: 1) Introduce the research content of executive compensation and corporate tax avoidance, analyze the research significance of this article, and the innovative points and shortcomings. 2) Through the study of relevant domestic and foreign documents, make a review, and further reflect the innovation and significance of this article. 3) Based on principal-agent theory, put forward the core hypothesis of the relationship between executive compensation and corporate tax avoidance. 4) Explain the reasons for time intervals and samples selecting, construct corresponding models, and explain how to select and measure variables. 5) Descriptive statistics, correlation analysis and regression analysis are carried out in groups to study the relationship between different forms of executive compensation incentives and the degree of corporate tax avoidance. 6) Adjust the method of measuring the degree of corporate tax avoidance and pass the robustness test to verify the reliability of the regression analysis. 7) According to the linear regression results, draw conclusions and make reasonable suggestions on taxation at the government level and corporate incentives for executive compensation.

\section{Literature Review}

\subsection{Monetary Compensation and Tax Avoidance}

Fewer people associate non-equity compensation (mainly including salary and bonuses) with tax incentives. Because executives are more sensitive to negative returns from cash compensation than to positive returns (Lambert \& Larker, 1987), the relationship between executive monetary compensation and tax avoidance is also of concern. Regarding non-equity compensation, Healy (1985) proposed cash compensation to encourage managers to focus on short-term goals. In the long run, incentive compensation is conducive to good tax management of enterprises (Minnick \& Noga, 2010). Some scholars believe that when the external risk is small, the company that pays the manager's excess cash 
compensation has a higher enthusiasm for tax avoidance (Lv \& Li, 2012; Huang et al., 2018). In addition, when executives perceive that their remuneration is lower than their peers, they may use their operating rights to use the cash flow from tax avoidance as their implicit remuneration (Chen et al., 2009), that is, when incentives are insufficient, executives are likely to increase the degree of tax avoidance to obtain additional income. However, compared with equity incentives, cash compensation and bonus contracts are usually related to accounting returns, but not to stock returns (Duru et al., 2012). When the short-term interest rate is adjusted, managers whose incentive compensation is in the form of cash will reduce tax avoidance activities (Huang et al., 2018). Chen \& Tang (2012) believe that the low tax avoidance effect caused by high salaries is more significant in companies with poor governance. In addition, compared with state-owned holding companies, non-state-owned holding companies' executive compensation has a more prominent effect on suppressing the degree of tax avoidance of enterprises (Sun \& Wang, 2018).

\subsection{Equity Incentives and Tax Avoidance}

The reason why equity incentives can link company performance with personal wealth in the enterprise (Hall \& Murphy, 2002) is based on the theory of agency that can improve the consistency of the interests of managers and shareholders, naturally reducing the agency conflicts between the two (Jensen \& Meckling 1976). Financial accounting incentives mechanism does play a role in tax planning strategies (Graham et al., 2014). Specific to how exactly incentives affect corporate tax management, some scholars hold a similar or consistent view that the higher the executive equity incentives, the stronger the willingness to avoid tax (Liu et al., 2010). However, some scholars have drawn different results. Desai \& Dharmapala (2006) found that under the complementary relationship between the tax asylum of managers' rent-seeking behavior and the potential benefits of managers' transfer of tax avoidance, increasing incentive compensation may reduce the level of tax avoidance. For further research, adding tax rate volatility factors, Armstrong et al. (2015) believe that there is a positive correlation between compensation for equity incentives and tax positivity, while Peng (2017) found that fluctuations in tax rates make equity incentives and corporate tax avoidance present $U$ ' type relationship. In addition, by distinguishing the nature of property rights, it is found that with the increase of incentive rewards for managers, state-owned holding companies will reduce corporate tax avoidance, while private holding companies and foreign holding companies will increase corporate tax avoidance (Liu et al., 2010).

It can be seen from the review of the existing literature that relevant research also has the following limitations: 1) Few pieces of literature considers the impact of executive monetary compensation incentives and equity incentives on corporate tax avoidance at the same time; 2) No further consideration is given to companies that are under different attributes of property rights, different types of salary incentives have different effects on the degree of tax avoidance of en- 
terprises. The main contribution of this article: 1) Considering the impact of different types of salary incentives on the degree of tax avoidance of enterprises at the same time; 2) Considering the property rights of listed companies and the possible rent-seeking behaviors of executives, executives of state-owned and non-state-owned enterprises have taken different measures to avoid tax.

\section{Theoretical Analysis and Research Hypothesis}

Generally speaking, no matter what form of salary incentive method is to coordinate the principal-agent problem caused by information asymmetry between shareholders and management (Jensen \& Meckling, 1976). Linking management and shareholders' interests through executives' shareholding and remuneration affects their performance, etc. so that the expectations of executives and shareholders are consistent, then the shareholders' wealth can be maximized. However, based on the principal-agent theory, different types of property rights have various intensities of tax avoidance. Compared with state-owned holding companies, the goals and missions of non-state holding companies are more straightforward and single, that is, the maximization of corporate value. Executives expect more economic benefits than anything else. Therefore, due to incentives making executives more motivated to pursue higher after-tax profits, executives are likely to use tax avoidance to achieve such motives. Based on the above analysis, this article proposes the following assumptions:

$\mathrm{H}_{1}$ : In non-state-owned holding enterprises, the monetary compensation of executives is significantly positively correlated with the degree of corporate tax avoidance.

$\mathrm{H}_{2}$ : In non-state-owned holding enterprises, the equity incentive of executives is significantly positively correlated with the degree of corporate tax avoidance.

China is a socialist market economy, which is significantly different from Western capital markets. Western enterprises are basically non-state-owned enterprises, but due to the unique form of social consciousness in our country, state-owned holding enterprises are an important part of Chinese enterprises. Compared with non-state holding enterprises, non-state holding enterprises have a higher non-tax cost, which makes the tax management of the two different. First, increased supervision will lead to a reduction in rent-seeking space. Tax avoidance has a feedback effect on executive rent-seeking. The more tax avoidance behaviors, the more self-interest behaviors by using positions are more likely to be covered up and put into practice, which in turn increases the internal impulse for executives to implement tax avoidance. Cheng \& Warfield (2005) conducted a case analysis by using tax avoidance transactions to manipulate profits and found evidence that management seeks to obtain self-interest through tax avoidance. Therefore, the reduction of rent-seeking behavior has suppressed the tax avoidance behavior of enterprises. In addition, executives of state-owned holding companies not only seek economic wealth, but also pursue their own good reputation, credit, and future political path. Therefore, execu- 
tives of state-owned holding companies need to bear greater risks and pressures when deciding to avoid tax, thereby reducing their desire to pursue high after-tax profits. The above-mentioned reasons will cause any kind of incentive compensation to be of low utility to executives. It should be noted that the form of remuneration incentives is divided into monetary remuneration and equity incentives in this paper. Compared with non-state-holding companies, monetary remuneration of executives in state-owned holding companies generally does not depend on the company's operating performance and there is almost no piece-rate reward system, performance-based salary increase and other forms of salary. That is, the fluctuation of its monetary remuneration is small, and there is basically no major change. Based on the above analysis, this article proposes the following assumptions:

$\mathrm{H}_{3}$ : In state-owned holding enterprises, there is no significant relationship between executives' monetary remuneration and the degree of tax avoidance.

$\mathrm{H}_{4}$ : In state-owned holding enterprises, the equity incentive of executives is significantly negatively correlated with the degree of corporate tax avoidance.

\section{Research Design}

\subsection{Sample Selection and Data Source}

Since the 18th National Congress of the Communist Party of China, the party and the state have greatly strengthened their anti-corruption efforts. In particular, the investigation and punishment of anti-corruption executives have attracted much attention. Under the background of increased supervision by the state, this will lead to changes in corporate tax avoidance behavior. In addition, considering the nature of corporate property rights, the impact of relevant policies on state-owned holding companies and non-state-holding companies is different. Therefore, this paper selects 2013 as the initial year of truncation for this study and defers it for 5 years as the time interval for the study. Divide all listed companies based on the nature of their property rights as the sample interval for the study.

This article takes all listed companies in China from 2013 to 2018 as the initial sample, and the relevant data are derived from the CSMAR database. Filter it as follows:

First, the information disclosure of financial and insurance industry companies is special, and there are obvious differences in their accrued profits, which are not suitable as samples. Therefore, listed companies in the financial and insurance industry are excluded. Second, the listed companies whose data are incomplete due to various reasons such as new listing, suspension of listing and ST during the data period are excluded. Third, remove extreme values in variables.

\subsection{Model Design}

In order to verify the research hypothesis, this paper constructed the following models: 


$$
\begin{aligned}
& E_{T R R_{i, t}}=\beta_{0}+\beta_{1} C T R_{i, t}+\beta_{2} L E V_{i, t}+\beta_{3} \operatorname{SIZE}_{i, t}+\beta_{4} R O A_{i, t} \\
& +\beta_{5} \text { GROWTH }_{i, t}+\beta_{6} \mathrm{TOP}_{i, t}+\varepsilon_{i, t} \\
& \operatorname{ETR}_{i, t}=\beta_{7}+\beta_{8} M_{R S_{i, t}}+\beta_{9} L E V_{i, t}+\beta_{10} S_{Z I E}+\beta_{11} R O A_{i, t} \\
& +\beta_{12} \text { GROWTH }_{i, t}+\beta_{13} \text { TOP }_{i, t}+\varepsilon_{i, t}
\end{aligned}
$$

It is worth noting that this paper divides the sample into state-owned holding enterprises and non-state-owned holding enterprises. Substituting the above two types of property rights into the model for testing, and then the effects caused by setting dummy variables can be excluded.

\subsection{Variable Measurement}

\subsubsection{Dependent Variable}

Regarding the measurement method of the tax avoidance degree of enterprises, scholars at home and abroad generally choose the following three methods. 1) Book Tax Difference (BTD) broadly defined it as the difference between the revenue figures announced to the capital market and the revenue figures reported to the capital market, which is further understood to be the accounting-tax difference. It can be used as an indicator that proves whether the attitude of corporate taxes is positive or negative. 2) The effective tax rate (ETR) is defined by GAAP. That is, the total income tax expense considering deferred income tax expense is divided by accounting profit before tax. 3) Cash tax rate means cash-based income tax expense is collected, and deferred income tax is not considered.

This article adopts the second method, namely effective tax rate ETR = (income tax expense-deferred income tax expense)/total profit. It should be noted that the effective tax rate (ETR) and the degree of tax avoidance are inversely related, that is, the higher the effective tax rate (ETR), the lower the degree of corporate tax avoidance.

\subsubsection{Independent Variables}

The independent variables in this article are executive monetary remuneration and equity incentives.

Among them, monetary remuneration is measured by the natural logarithm of the "total remuneration of the top three executives with the highest compensation" of listed companies. In this way, the problem that the data is too large and the variables are not in the same order of magnitude can be eliminated.

Regarding the measurement of equity incentives, domestic scholars generally use the index of executive shareholding ratio, that is, executive shareholding/total equity. There are generally two ways of measuring abroad. One is the view of Himmelberg (1997). When the company's stock price changes by $1 \%$, it results in the fluctuation of executive's options and restricted stocks. The other is that Jensen \& Murphy (1990) consider the floating trend of executives' stock and option remunerations with the change of corporate value.

This article uses the first foreign measurement methods listed above and con- 
siders the size of equity incentives from the perspective of stock price changes. That is, equity incentives $=$ (number of shares held by management ${ }^{\star}$ share price per share $\left.{ }^{\star} 1 \%\right) /($ sum of the remuneration of the managers whose remuneration ranking top $3+$ number of shares held by management ${ }^{\star}$ share price per share $\left.^{\star} 1 \%\right)$.

\subsubsection{Control Variables}

This paper refers to the research of many scholars and adopts the following control variables in the research model: asset-liability ratio (LEV), enterprise size (SIZE), return on net assets (ROE), company growth (GROWTH), the shareholding ratio of the largest shareholder (TOP1). Debt has the effect of a tax shield, which has a certain impact on enterprise tax savings, so the asset-liability ratio (LEV) needs to be controlled. Since the public view tends to focus on large enterprises, large-scale enterprises are more cautious in tax avoidance decisions. So it is necessary to control the size of enterprises (SIZE). Corporate profitability is related to actual tax rate, so the rate of return on total assets (ROA) is controlled. The growth level of operating income can also measure the profitability of the company to a certain extent, so controlling the growth of the company (GROWTH). The concentration of corporate equity has guidance to corporate strategy and affects corporate tax management to a certain extent, so the shareholding ratio of the largest shareholder (TOP1) is controlled.

The definitions of all variables in model $\mathrm{a}$ and model $\mathrm{b}$ are shown in Table 1.

Table 1. Definition of variables in regression model.

\begin{tabular}{|c|c|c|c|}
\hline & ariable name & Variable symbol & Variable definitions \\
\hline $\begin{array}{l}\text { Dependent } \\
\text { variable }\end{array}$ & Tax avoidance & ETR & $\begin{array}{l}\text { the effective tax rate }=\text { (income tax expense }- \text { deferred } \\
\text { income tax expense }) / \text { total profit }\end{array}$ \\
\hline \multirow[b]{2}{*}{$\begin{array}{l}\text { Independent } \\
\text { variable }\end{array}$} & $\begin{array}{l}\text { Executive monetary } \\
\text { remuneration }\end{array}$ & $C T R$ & $\begin{array}{l}\text { the natural logarithm of the "total remuneration of } \\
\text { the top three executives with the highest compensation" }\end{array}$ \\
\hline & Executive equity incentive & $M R S$ & $\begin{array}{l}\text { (number of shares held by management }{ }^{*} \text { share price } \\
\left.\text { per share }{ }^{\star} 1 \%\right) /(\text { sum of the remuneration of the } \\
\text { managers whose remuneration ranking top } 3+\text { number of } \\
\left.\text { shares held by management }{ }^{\star} \text { share price per share } 1 \%\right)\end{array}$ \\
\hline \multirow{5}{*}{$\begin{array}{l}\text { Control } \\
\text { variable }\end{array}$} & Asset-liability ratio & $L E V$ & total liabilities/total assets \\
\hline & Enterprise size & $S I Z E$ & the natural $\log$ of total assets \\
\hline & Return on total assets & $R O A$ & net profit/total assets \\
\hline & $\begin{array}{l}\text { Main business } \\
\text { income growth rate }\end{array}$ & GROWTH & $\begin{array}{l}\text { (amount of main business income this year - amount of } \\
\text { last year)/amount of last year }\end{array}$ \\
\hline & $\begin{array}{l}\text { The shareholding ratio } \\
\text { of the largest shareholder }\end{array}$ & TOP1 & $\begin{array}{l}\text { Shareholding ratio of shareholders } \\
\text { with the highest number of shares }\end{array}$ \\
\hline
\end{tabular}

Data source: Cathay pacific database. 


\section{Empirical Analysis and Results}

\subsection{Descriptive Statistics}

This article selects 2013-2018 as the sample interval, divides listed companies according to the nature of property rights, and carries out relevant descriptive analysis on the variables involved in the model. The statistical results are shown in Table 2 and Table 3.

In Table 2, the minimum value of the actual income tax rate (ETR) of the selected sample of non-state-controlled listed companies is -0.465 , and the maximum value is 0.851 , indicating that there is a large difference in the actual income tax rate of China's non-state holding companies. That is, the intensity of tax avoidance varies greatly. The average value of the actual income tax rate is 0.169 , and the standard deviation is 0.141 , indicating that the actual income tax rate fluctuates slightly. The minimum value in monetary compensation incentives (CTR) is 12.142 and the maximum value is 17.420 . That shows monetary

Table 2. Descriptive analysis of non-state-owned holding companies (Full samples $\mathrm{N}=$ 2367).

\begin{tabular}{ccccc}
\hline Variables & Average & Standard deviation & Minimum & Maximum \\
\hline ETR & 0.169 & 0.141 & -0.465 & 0.851 \\
CTR & 14.399 & 0.638 & 12.142 & 17.420 \\
MRS & 0.845 & 0.171 & 0.065 & 0.996 \\
LEV & 0.376 & 0.184 & 0.009 & 1.685 \\
SIZE & 21.96 & 0.94 & 17.388 & 26.298 \\
ROA & 0.039 & 0.119 & -3.994 & 0.482 \\
GROWTH & -0.725 & 14.126 & -310.273 & 363.068 \\
TOP1 & 0.303 & 0.132 & 0.041 & 0.800 \\
\hline
\end{tabular}

Data source: Cathay pacific database.

Table 3. Descriptive analysis of state-owned holding companies (Full samples $\mathrm{N}=706$ ).

\begin{tabular}{ccccc}
\hline Variables & Average & Standard deviation & Minimum & Maximum \\
\hline ETR & 0.214 & 0.348 & -1.340 & 1.943 \\
CTR & 14.836 & 0.713 & 13.134 & 17.261 \\
MRS & 0.176 & 0.234 & 0.001 & 0.868 \\
LEV & 0.509 & 0.191 & 0.090 & 0.976 \\
SIZE & 23.168 & 1.371 & 20.306 & 28.253 \\
ROA & 0.033 & 0.060 & -0.651 & 0.205 \\
GROWTH & -0.616 & 5.667 & -84.134 & 31.355 \\
TOP1 & 0.341 & 0.145 & 0.036 & 0.818 \\
\hline
\end{tabular}

Data source: Cathay pacific database. 
remuneration paid to the management has a significant difference in the non-state-owned holding listed company in China. It may be caused by the company's operating performance and the remuneration contract signed with the executives. The minimum value in equity incentives (MRS) is 0.065 and the maximum value is 0.996 , indicating that the level of shareholding of executives of different companies is inconsistent, that is, the difference in shareholding incentives is obvious.

In Table 3, in state-owned holding listed companies, the minimum value of the actual income tax rate (ETR) of the selected sample is -1.340 , the maximum value is 1.943 , and the standard deviation is 0.214 . It shows that the actual income tax rate of non-state holding companies in my country is quite different, that is, there are certain differences in tax management. The minimum value of the monetary compensation incentive (CTR) is 13.134 , and the maximum value is 17.261. This shows that there is a significant difference in the monetary remuneration paid to management in state-owned holding listed companies in China. The minimum value in equity incentive (MRS) is 0.001 and the maximum value is 0.868 , indicating that the level of holdings of executives of different companies is inconsistent, that is, the difference in shareholding incentives is obvious.

In addition, as can be seen from Table 2 and Table 3, whether it is a nonstate-controlled company or a state-controlled company, the asset-liability ratio (LEV), enterprise size (SIZE), return on net assets (ROA), company growth (GROWTH) and the largest shareholder's shareholding ratio (TOP1) the minimum and maximum values are very different. This shows that each company's ability to use debt leverage, enterprise size, profitability, growth capability and their corresponding concentration of equity have nothing in common. In particular, the huge standard deviation of the company's growth indicates that the main business growth capabilities of the companies are far from each other.

\subsection{Correlation Analysis}

As can be seen from Table 4 and Table 5, for Model 1, in non-state-owned holding companies, there is a positive correlation between executive monetary compensation (CTR) and effective tax rate (ETR). Executive equity incentives (MRS) and effective tax rates (ETR) are negatively correlated, but the result is not significant. For model two, executive currency compensation (CTR) and effective tax rate (ETR) have a negative correlation and are significant at the 5\% level. Executive incentive compensation (CTR) and effective tax rate (ETR) are positively correlated, but not significant. For model one, the asset-liability ratio (LEV), company size (SIZE), total asset return (ROA) and effective tax rate (ETR) are significantly positively correlated at $1 \%$, while for model two, the relationship is precisely opposite. Moreover none is significant correlation. In the first model, the proportion of the largest shareholder's shareholding (TOP1) and the effective tax rate (ETR) are positively related. However, in the second model, 
Table 4. Correlation coefficients of non-state-owned holding companies.

\begin{tabular}{|c|c|c|c|c|c|c|c|c|c|}
\hline & & ETR & CTR3 & MRSH & LEV & SIZE & ROA & GROWTH & TOP1 \\
\hline ETR & $\begin{array}{c}\text { Correlation } \\
\text { Distinctiveness }\end{array}$ & 1 & & & & & & & \\
\hline CTR & $\begin{array}{c}\text { Correlation } \\
\text { Distinctiveness }\end{array}$ & $\begin{array}{l}0.011 \\
0.599\end{array}$ & 1 & & & & & & \\
\hline MRS & $\begin{array}{c}\text { Correlation } \\
\text { Distinctiveness }\end{array}$ & $\begin{array}{c}-0.035 \\
0.090\end{array}$ & $\begin{array}{c}-0.328^{\star *} \\
0.000\end{array}$ & 1 & & & & & \\
\hline LEV & $\begin{array}{c}\text { Correlation } \\
\text { Distinctiveness }\end{array}$ & $\begin{array}{c}0.084^{\star *} \\
0.000\end{array}$ & $\begin{array}{c}0.143^{\star *} \\
0.000\end{array}$ & $\begin{array}{c}-0.194^{\star *} \\
0.000\end{array}$ & 1 & & & & \\
\hline SIZE & $\begin{array}{c}\text { Correlation } \\
\text { Distinctiveness }\end{array}$ & $\begin{array}{c}0.100^{\star *} \\
0.000\end{array}$ & $\begin{array}{c}0.484^{\star *} \\
0.000\end{array}$ & $\begin{array}{c}-0.054^{\star *} \\
0.008\end{array}$ & $\begin{array}{c}0.473^{\star *} \\
0.000\end{array}$ & 1 & & & \\
\hline ROA & $\begin{array}{c}\text { Correlation } \\
\text { Distinctiveness }\end{array}$ & $\begin{array}{c}0.120^{\star *} \\
0.000\end{array}$ & $\begin{array}{c}0.063^{\star *} \\
0.002\end{array}$ & $\begin{array}{c}0.095^{\star \star} \\
0.000\end{array}$ & $\begin{array}{c}-0.246^{\star *} \\
0.000\end{array}$ & $\begin{array}{c}0.053^{\star *} \\
0.010\end{array}$ & 1 & & \\
\hline GROWTH & $\begin{array}{c}\text { Correlation } \\
\text { Distinctiveness }\end{array}$ & $\begin{array}{l}0.013 \\
0.522\end{array}$ & $\begin{array}{c}-0.005 \\
0.813\end{array}$ & $\begin{array}{c}0.089^{\star *} \\
0.000\end{array}$ & $\begin{array}{l}0.033 \\
0.107\end{array}$ & $\begin{array}{c}0.060^{\star *} \\
0.003\end{array}$ & $\begin{array}{l}0.026 \\
0.201\end{array}$ & 1 & \\
\hline TOP1 & $\begin{array}{c}\text { Correlation } \\
\text { Distinctiveness }\end{array}$ & $\begin{array}{l}0.036 \\
0.077\end{array}$ & $\begin{array}{c}-0.037 \\
0.074\end{array}$ & $\begin{array}{c}-0.027 \\
0.191\end{array}$ & $\begin{array}{c}-0.052^{\star} \\
0.011\end{array}$ & $\begin{array}{c}-0.057^{\star \star} \\
0.005\end{array}$ & $\begin{array}{c}0.128^{\star *} \\
0.000\end{array}$ & $\begin{array}{c}-0.004 \\
0.828\end{array}$ & 1 \\
\hline
\end{tabular}

Note: ${ }^{* *} p<0.01$, indicating significant at the $1 \%$ level; ${ }^{* *} p<0.05$, indicating significant at the $5 \%$ level; ${ }^{*} p<0.1$, indicating significant at the $10 \%$ level. Data source: Cathay pacific database.

Table 5. Correlation coefficients of state-owned holding companies.

\begin{tabular}{|c|c|c|c|c|c|c|c|c|c|}
\hline & & ETR & CTR3 & MRSH & LEV & SIZE & ROA & GROWTH & TOP1 \\
\hline ETR & $\begin{array}{c}\text { Correlation } \\
\text { Distinctiveness }\end{array}$ & 1 & & & & & & & \\
\hline CTR & $\begin{array}{c}\text { Correlation } \\
\text { Distinctiveness }\end{array}$ & $\begin{array}{c}-0.076^{\star} \\
0.043\end{array}$ & 1 & & & & & & \\
\hline MRS & $\begin{array}{c}\text { Correlation } \\
\text { Distinctiveness }\end{array}$ & $\begin{array}{l}0.060 \\
0.112\end{array}$ & $\begin{array}{c}-0.057 \\
0.132\end{array}$ & 1 & & & & & \\
\hline LEV & $\begin{array}{c}\text { Correlation } \\
\text { Distinctiveness }\end{array}$ & $\begin{array}{c}-0.022 \\
0.551\end{array}$ & $\begin{array}{c}0.200^{* *} \\
0.000\end{array}$ & $\begin{array}{c}-0.146^{\star \star} \\
0.000\end{array}$ & 1 & & & & \\
\hline SIZE & $\begin{array}{c}\text { Correlation } \\
\text { Distinctiveness }\end{array}$ & $\begin{array}{c}-0.032 \\
0.390\end{array}$ & $\begin{array}{c}0.549^{\star *} \\
0.000\end{array}$ & $\begin{array}{c}-0.115^{\star \star} \\
0.002\end{array}$ & $\begin{array}{c}0.498^{\star *} \\
0.000\end{array}$ & 1 & & & \\
\hline ROA & $\begin{array}{c}\text { Correlation } \\
\text { Distinctiveness }\end{array}$ & $\begin{array}{c}-0.031 \\
0.411\end{array}$ & $\begin{array}{c}0.239^{* *} \\
0.000\end{array}$ & $\begin{array}{l}0.047 \\
0.214\end{array}$ & $\begin{array}{c}-0.260^{\star *} \\
0.000\end{array}$ & $\begin{array}{c}0.114^{\star *} \\
0.003\end{array}$ & 1 & & \\
\hline GROWTH & $\begin{array}{c}\text { Correlation } \\
\text { Distinctiveness }\end{array}$ & $\begin{array}{l}0.003 \\
0.937\end{array}$ & $\begin{array}{c}0.093^{*} \\
0.013\end{array}$ & $\begin{array}{l}0.048 \\
0.203\end{array}$ & $\begin{array}{c}0.111^{\star *} \\
0.003\end{array}$ & $\begin{array}{c}0.161^{\star \star} \\
0.000\end{array}$ & $\begin{array}{c}0.080^{*} \\
0.034\end{array}$ & 1 & \\
\hline TOP1 & $\begin{array}{c}\text { Correlation } \\
\text { Distinctiveness }\end{array}$ & $\begin{array}{c}-0.052 \\
0.169\end{array}$ & $\begin{array}{c}-0.010 \\
0.784\end{array}$ & $\begin{array}{c}-0.224^{\star *} \\
0.000\end{array}$ & $\begin{array}{c}-0.071 \\
0.058\end{array}$ & $\begin{array}{c}0.113^{\star \star} \\
0.003\end{array}$ & $\begin{array}{c}0.129^{\star *} \\
0.001\end{array}$ & $\begin{array}{l}0.013 \\
0.722\end{array}$ & 1 \\
\hline
\end{tabular}

Note: ${ }^{* * *} p<0.01$, indicating significant at the $1 \%$ level; ${ }^{* *} p<0.05$, indicating significant at the $5 \%$ level; ${ }^{\star} p<0.1$, indicating significant at the $10 \%$ level. Data source: Cathay pacific database. 
the relationship between the two is reversed, and is not significant. Whether it is Model 1 or Model 2, company growth (GROWTH) and effective tax rate (ETR) are positively correlated and are not significant. This provides a preliminary explanation for the next step of regression analysis.

\subsection{Regression Analysis}

For model one, through the Hausman test, it is found that:

$$
\begin{gathered}
\operatorname{chi} 2(8)=(b-B)^{\prime}\left[\left(V_{b}-V_{B}\right)^{-1}\right](b-B)=6.28 \\
\text { Prob }>\text { chi } 2=0.6155
\end{gathered}
$$

Therefore, choosing random effects for regression analysis. Table 6 shows the regression results.

For model one, through the Hausman test, it is found that:

$$
\begin{gathered}
\operatorname{chi} 2(7)=(b-B)^{\prime}\left[\left(V_{b}-V_{B}\right)^{-1}\right](b-B)=35.87 \\
\text { Prob }>\text { chi } 2=0.0000
\end{gathered}
$$

Therefore, choosing fixed effects for regression analysis. Table 7 shows the regression results.

The regression results of model a can be concluded that in non-state-owned holding companies, executive monetary compensation (CTR) and effective tax rate (ETR) are significantly negatively correlated at $1 \%$, executive equity incentive (MRS) and effective tax rate (ETR) are significantly negatively correlated at the $5 \%$ level. The lower the effective tax rate, the higher the degree of corporate tax avoidance. Therefore, executive monetary compensation and equity incentives

Table 6. Regression analysis of non-state-owned holding companies.

\begin{tabular}{ccccc}
\hline ETR & $\begin{array}{c}\text { Regression } \\
\text { coefficients }\end{array}$ & $\begin{array}{c}\text { Coefficient } \\
\text { standard deviation }\end{array}$ & $\begin{array}{c}\text { Coefficient } \\
t \text { statistic }\end{array}$ & $p$ \\
\hline Constant & 0.101 & 0.094 & 1.08 & 0.279 \\
CTR & $-0.016^{* * *}$ & 0.006 & -2.63 & 0.008 \\
MRS & $-0.042^{* *}$ & 0.020 & -2.16 & 0.031 \\
LEV & $0.055^{* * *}$ & 0.020 & 2.71 & 0.007 \\
SIZE & $0.013^{* * *}$ & 0.004 & 3.06 & 0.002 \\
ROA & $0.169^{* * *}$ & 0.025 & 6.69 & 0.000 \\
GROWTH & 0.000 & 0.000 & 0.52 & 0.601 \\
TOP1 & 0.029 & 0.024 & 1.23 & 0.220 \\
Adj-R & & 0.034 & & \\
F & & 4.12 & & \\
\hline
\end{tabular}

Note: ${ }^{* *} p<0.01$, indicating significant at the $1 \%$ level; ${ }^{* *} p<0.05$, indicating significant at the $5 \%$ level; ${ }^{\star} p<0.1$, indicating significant at the $10 \%$ level. Data source: Cathay pacific database. 
Table 7. Regression analysis of state-owned holding companies.

\begin{tabular}{ccccc}
\hline ETR & $\begin{array}{c}\text { Regression } \\
\text { coefficients }\end{array}$ & $\begin{array}{c}\text { Coefficient } \\
\text { standard deviation }\end{array}$ & $\begin{array}{c}\text { Coefficient } \\
t \text { statistic }\end{array}$ & $p$ \\
\hline Constant & -110.223 & 90.814 & -1.21 & 0.225 \\
CTR & 2.747 & 3.770 & 0.73 & 0.467 \\
MRS & $54.266^{* * *}$ & 10.752 & 5.05 & 0.000 \\
LEV & -11.515 & 18.504 & -0.62 & 0.534 \\
SIZE & 3.731 & 4.061 & 0.92 & 0.359 \\
ROA & 18.378 & 28.840 & 0.64 & 0.524 \\
GROWTH & -0.052 & 0.245 & -0.21 & 0.831 \\
TOP1 & $-58.693^{* *}$ & 25.614 & -2.29 & 0.022 \\
Adj-R & & 0.071 & & \\
F & & 5.06 & & \\
\hline
\end{tabular}

Note: ${ }^{* *} p<0.01$, indicating significant at the $1 \%$ level; ${ }^{* *} p<0.05$, indicating significant at the $5 \%$ level; ${ }^{*} p<0.1$, indicating significant at the $10 \%$ level. Data source: Cathay pacific database.

are significantly positively related to corporate tax avoidance. Suppose $\mathrm{H}_{1}$ and $\mathrm{H}_{2}$ are both true.

The regression results of model $b$ can be concluded that in state-owned holding companies, executive monetary compensation (CTR) and effective tax rate (ETR) are positively correlated, but not significant. That is to say, there is no significant relationship between executive monetary compensation and corporate tax avoidance. Executive equity incentive (MRS) and effective tax rate (ETR) are significantly positively correlated at $1 \%$. The lower the effective tax rate, the higher the degree of corporate tax avoidance. Therefore, equity incentives are significantly positively related to corporate tax avoidance. Suppose $\mathrm{H}_{3}$ and $\mathrm{H}_{4}$ are both true.

The regression results further illustrate that different property rights and incentive methods will have different effects on the tax avoidance behavior of enterprises. For non-state-owned holding company executives, they pay more attention to their own economic interests, so when they are encouraged, they tend to increase the degree of tax avoidance. In this way, the company's after-tax profits and value can be improved. Finally, it reflects that they themselves obtained greater benefits. However, for executives of state-owned holding companies, they pay more attention to their political careers than wealth. And under the strict supervision mechanism, the rent-seeking space is reduced, and the greater risk cost will further inhibit its aggressive tax avoidance strategy.

\section{Robustness Test}

For different enterprises, China has formulated corresponding tax policies. To 
ensure the robustness of the conclusion, this paper expresses the degree of corporate tax avoidance (RE) as the difference between the nominal income tax rate and the actual income tax rate. The regression results are shown in Table 8 and Table 9. In addition, $10 \%-90 \%$ of the corporate tax avoidance degree (RE) is selected and the regression was performed again after the extreme value was removed. The regression results are shown in Table 10 and Table 11.

Table 8. Regression analysis of non-state-owned holding companies.

\begin{tabular}{ccccc}
\hline RE & $\begin{array}{c}\text { Regression } \\
\text { coefficients }\end{array}$ & $\begin{array}{c}\text { Coefficient } \\
\text { standard deviation }\end{array}$ & $\begin{array}{c}\text { Coefficient } \\
t \text { statistic }\end{array}$ & $p$ \\
\hline Constant & 0.051 & 1.382 & 0.04 & 0.971 \\
CTR & $0.206^{* * *}$ & 0.076 & 2.71 & 0.007 \\
MRS & $0.018^{* *}$ & 0.149 & 0.12 & 0.064 \\
LEV & -0.002 & 0.272 & -0.01 & 0.994 \\
SIZE & $-0.133^{* *}$ & 0.065 & -2.05 & 0.041 \\
RO & -0.224 & 0.228 & -0.98 & 0.326 \\
GROWTH & 0.001 & 0.002 & 0.67 & 0.502 \\
TOP1 & -0.255 & 0.534 & -0.48 & 0.634 \\
Adj-R & & 0.016 & & \\
F & & 1.44 & & \\
\hline
\end{tabular}

Note: ${ }^{* *} p<0.01$, indicating significant at the $1 \%$ level; ${ }^{* *} p<0.05$, indicating significant at the $5 \%$ level; ${ }^{\star} p<0.1$, indicating significant at the $10 \%$ level. Data source: Cathay pacific database.

Table 9. Regression analysis of state-owned holding companies.

\begin{tabular}{ccccc}
\hline RE & $\begin{array}{c}\text { Regression } \\
\text { coefficients }\end{array}$ & $\begin{array}{c}\text { Coefficient } \\
\text { standard deviation }\end{array}$ & $\begin{array}{c}\text { Coefficient } \\
t \text { statistic }\end{array}$ & $p$ \\
\hline Constant & 1.986 & 37.840 & 0.05 & 0.958 \\
CTR & -0.479 & 1.581 & -0.30 & 0.762 \\
MRS & $-19.004^{* * *}$ & 4.999 & -3.80 & 0.000 \\
LEV & -2.503 & 7.014 & -0.36 & 0.721 \\
SIZE & -0.582 & 1.659 & -0.35 & 0.726 \\
ROA & -14.221 & 9.891 & -1.44 & 0.151 \\
GROWTH & 0.010 & 0.044 & 0.24 & 0.814 \\
TOP1 & 20.626 & 10.398 & 1.98 & 0.048 \\
Adj-R & & 0.019 & & \\
F & & 3.09 & & \\
\hline
\end{tabular}

Note: ${ }^{* *} p<0.01$, indicating significant at the $1 \%$ level; ${ }^{* *} p<0.05$, indicating significant at the $5 \%$ level; ${ }^{\star} p<0.1$, indicating significant at the $10 \%$ level. Data source: Cathay pacific database. 
Table 10. Regression analysis of non-state-owned holding companies.

\begin{tabular}{ccccc}
\hline RE & $\begin{array}{c}\text { Regression } \\
\text { coefficients }\end{array}$ & $\begin{array}{c}\text { Coefficient } \\
\text { standard deviation }\end{array}$ & $\begin{array}{c}\text { Coefficient } \\
t \text { statistic }\end{array}$ & $p$ \\
\hline Constant & 0.060 & 0.042 & 1.42 & 0.155 \\
CTR & $0.030^{* * *}$ & 0.014 & 2.14 & 0.021 \\
MRS & $0.046^{* *}$ & 0.022 & 2.05 & 0.086 \\
LEV & $-0.116^{* * *}$ & 0.031 & -3.74 & 0.000 \\
SIZE & -0.019 & 0.010 & -1.91 & 0.139 \\
ROA & $-0.079^{* *}$ & 0.027 & -2.96 & 0.014 \\
GROWTH & 0.002 & 0.002 & 0.91 & 0.364 \\
TOP1 & -0.157 & 0.099 & -1.58 & 0.152 \\
Adj-R & & 0.062 & & \\
F & & 4.20 & & \\
\hline
\end{tabular}

Note: ${ }^{* *} p<0.01$, indicating significant at the $1 \%$ level; ${ }^{* *} p<0.05$, indicating significant at the $5 \%$ level; ${ }^{*} p<0.1$, indicating significant at the $10 \%$ level. Data source: Cathay pacific database.

Table 11. Regression analysis of state-owned holding companies.

\begin{tabular}{ccccc}
\hline RE & $\begin{array}{c}\text { Regression } \\
\text { coefficients }\end{array}$ & $\begin{array}{c}\text { Coefficient } \\
\text { standard deviation }\end{array}$ & $\begin{array}{c}\text { Coefficient } \\
t \text { statistic }\end{array}$ & $p$ \\
\hline Constant & 0.085 & 0.197 & 4.31 & 0.000 \\
CTR & 0.002 & 0.341 & 0.01 & 0.995 \\
MRS & $-0.017^{* *}$ & 0.008 & -2.01 & 0.045 \\
LEV & -0.065 & 0.044 & -1.46 & 0.144 \\
SIZE & $-0.023^{* * *}$ & 0.008 & -2.75 & 0.006 \\
ROA & $-0.265^{* * *}$ & 0.085 & -3.12 & 0.002 \\
GROWTH & 0.003 & 0.006 & -0.62 & 0.537 \\
TOP1 & 0.046 & 0.067 & -0.68 & 0.497 \\
Adj-R & & 0.035 & & \\
F & & 4.14 & & \\
\hline
\end{tabular}

Note: ${ }^{\star *} p<0.01$, indicating significant at the $1 \%$ level; ${ }^{\star *} p<0.05$, indicating significant at the $5 \%$ level; ${ }^{*} p<0.1$, indicating significant at the $10 \%$ level. Data source: Cathay pacific database.

Based on the results in Tables 8-11, we can see that among non-state-owned holding companies, the executive currency compensation (CTR), executive equity incentives (MRS), and the difference between the nominal income tax and the effective tax rate (RE) are significantly positively correlated relationship. That is, the higher the monetary compensation and equity incentives of executives, the higher their enthusiasm for tax avoidance. Among state-owned holding 
companies, the executive currency compensation (CTR) is negatively correlated with the difference between the nominal income tax and the effective tax rate (RE), but not significant. Executive equity compensation (MRS) and the difference between the nominal income tax and the effective tax rate (RE) have a significantly negative correlation, that is, the higher the equity incentive, the higher the tax avoidance inhibition of the company. The conclusions are consistent with the original hypothesis. The results of robustness test are consistent with the original empirical results

\section{Conclusion and Recommendations}

This article takes all listed companies in China from 2013 to 2018 as the research object and empirically analyzes the relationship between executive compensation incentives and corporate tax avoidance behaviors. The research results confirm that different forms of executive compensation incentives have diverse effects on enterprises which property rights are not the same. For non-state-owned holding enterprises, higher executive monetary compensation and equity incentives play a role in promoting tax avoidance. While for state-owned holding enterprises, executive monetary compensation has nothing to do with tax avoidance, besides, higher equity incentives have Inhibition on tax avoidance. For companies, a good compensation incentive contract should be established between shareholders and executives, which can maximize corporate value and form effective and reasonable corporate tax management decisions, and always warn enterprises that if they do not pay taxes in accordance with the law, they will face significant punishment. Under strict supervision, non-tax costs of state-owned holding companies have further increased, so corporate rent-seeking has decreased. In addition, executives of state-owned holding companies are more concerned about the promotion of positions and other goals than benefits. Therefore, state-owned holding companies have greatly reduced their enthusiasm for tax avoidance. However, for non-state holding companies, the tax department still needs to pay more attention to them and further strengthen supervision and control, so that enterprises of various economic components in China can contribute to socialist market economy.

\section{Project}

Postgraduate Research \& Practice Innovation Program of Jiangsu Province (KYCX21_2764).

\section{Conflicts of Interest}

The authors declare no conflicts of interest regarding the publication of this paper.

\section{References}

Armstrong, C. S., Blouin, J. L., Jagolinzer, A. D., \& Larcker, D. F. (2015). Corporate Go- 
vernance, Incentives, and Tax Avoidance. Journal of Accounting and Economics, 60, 1-17. https://doi.org/10.1016/j.jacceco.2015.02.003

Chen, B., \& Jiang, B. D. (2021). Anti-Tax Avoidance Legislation, Tax Collection and Administration and Corporate Related Transaction Tax Avoidance Behavior. Finance and Accounting Monthly, No. 13, 153-160.

Chen, D., \& Tang, J. X. (2012). Executive Compensation, Tax Avoidance, Rent-Seeking and Accounting Information Disclosure. Economic Management, 34, 114-122.

Chen, X. Y., Chen, D. H., Wan, H. L., \& Liang, S. K. (2009). Regional Differences, Salary Control and Executive Corruption. Management World, No. 11, 130-143+188.

Cheng, Q., \& Warfield, T. (2005). Equity Incentives and Earnings Management. The Accounting Review, 80, 441-476. https://doi.org/10.2308/accr.2005.80.2.441

Desai, M. A., \& Dharmapala, D. (2006). Corporate Tax Avoidance and High-Powered Incentives. Journal of Financial Economics, 79, 145-179.

https://doi.org/10.1016/j.jfineco.2005.02.002

Duru, A., Iyengar, R. J., \& Zampelli, E. M. (2012). Performance Choice, Executive Bonuses and Corporate Leverage. Corp Finance, 18, 1286-1305. https://doi.org/10.1016/j.jcorpfin.2012.08.003

Graham, J. R., Hanlon, M., Shevlin, T., \& Shroff, N. (2014). Tax Rates and Corporate Decision-Making. Accounting Review, 89, 991-1023. https://doi.org/10.2308/accr-50678

Hall, B. J., \& Murphy, K. J. (2002). Stock Options for Undiversified Executives. Journal of Accounting and Economics, 33, 3-42. https://doi.org/10.1016/S0165-4101(01)00050-7

Healy, P. (1985). The Effect of Bonus Schemes on Accounting Decisions. Journal of Accounting and Economics, 7, 85-107. https://doi.org/10.1016/0165-4101(85)90029-1

Himmelberg, C. P., Hubbard, R. G., \& Palia, D. (1997). Understanding the Determinants of Managerial Ownership and the Link between Ownership and Performance-An Investigation of Share Ownership and Corporate Performance. Journal of Financial Economics, 52, 353-384. https://doi.org/10.1016/S0304-405X(99)00025-2

Jensen, M., \& Meckling, W. (1976). Theory of the FRM: Managerial Behavior, Agency Costs and Ownership Structure. Journal of Financial Economics, 3, 305-360. https://doi.org/10.1016/0304-405X(76)90026-X

Jensen, M. C., \& Murphy, K. J. (1990). Performance Pay and Top-Management Incentives. Journal of Political Economy, 98, 225-264. https://doi.org/10.1086/261677

Lambert, R., \& Larcker, D. (1987). An Analysis of the Use of Accounting and Market Measures of Performance in Executive Compensation Contracts. Accounting Research Journal, 25, 85-125. https://doi.org/10.2307/2491081

Liu, H., Liu, J., \& Zhang, T. M. (2010). An Empirical Analysis of the Relationship between Management Equity Incentives and Corporate Tax Avoidance. Foreign Tax, No. 12, 37-40.

Lv, W., \& Li, M. H. (2012). Executive Incentives, Regulatory Risks, and Corporate Tax Burden: An Empirical Study Based on Listed Manufacturing Companies. Journal of Shanxi University of Finance and Economics, 34, 71-78.

Minnick, K., \& Noga, T. (2010). Do Corporate Governance Characteristics Influence Tax Management? Corp Finance, 16, 703-718. https://doi.org/10.1016/j.jcorpfin.2010.08.005

Peng, S. Y. (2017). On the Relationship between Corporate Equity Incentives and Tax Avoidance. China Business Review, No. 3, 108-109.

Sun, Z. H., \& Wang, J. P. (2018). Nature of Property Rights, Executive Compensation and Tax Evasion. China Collective Economy, No. 7, 100-102. 
Wang, H.-L. (2018). Review of Equity Incentive and Corporate Finance Research. Accounting Research, No. 5, 52-58.

Huang, W., Ying, T. T., \& Shen, Y. (2018). Executive Cash Compensation and Tax Aggressiveness of Chinese Firms. Review of Quantitative Finance \& Accounting, 51, 1151-1180. https://doi.org/10.1007/s11156-018-0700-2

Wu, X. J. (2018). Tax Regulation, Auditor Industry Expertise and Corporate Tax Avoidance. Finance and Accounting Bulletin, No. 3, 13-17. 